\title{
The effects of one-day outdoor education on self- efficacy
}

\author{
Nuh Osman Yildiz ${ }^{1}$ \\ Güçlü Özen ${ }^{2}$ \\ Tayfun Gürkan Bostancı ${ }^{3}$
}

\begin{abstract}
Self-efficacy-sufficiency is defined as the belief of a person about how well s/he can perform the actions to deal with the problems which $\mathrm{s} /$ he confronts. The belief of self-efficacy determines whether the person will manifest the right behaviour when confronted with a problem, and how much effort s/he will put in and how insistent s/he will be to deal with the problem.

The process of learning based on individuals' learning from their own lives and experiences, and reflecting on what is learned from the experience is called experiential learning, and is used widely as a method of personal development and learning. Outdoor education based on the principle of learning by experience acts as a catalyst for getting the participants to leave their comfort zones through a set of unusual activities carried out in a different atmosphere, and for encouraging them to change and to understand themselves as well as others.

The study was in pre-test-post-test design as one group and data was collected by survey. The sample of survey is the same with target population of the study and composed of 90 university students ( 50 men - 40 women), who play an active role in the Community of Mountain Climbing and Outdoor Sports and who volunteer for outdoor education. Outdoor education lasted one day and was designed in accordance with the literature. The outdoor education programme consisted of an opening meeting in which participants discussed the things to be done, and topics such as the comfort zone, learning by experience, and transfer of behaviours, two high-level activities, and an initiative activity based on communication and problem solving.

The Self-efficacy Scale (SES) developed in 1982 by Sherer et al. was used for measurement. The Scale was adapted to Turkish and tested for validity and reliability by Gözüm and Aksayan (1999).

This study aims to determine the effects of a one-day outdoor activity on the perceived level of selfefficacy of the participating students. The statistical analyses conducted have shown that the outdoor activity did not lead to a significant difference as regards the independent variable of gender ( $p>.05)$, yet it had a significant positive effect on the perceived self-efficacy of the participants $(\mathrm{p}<.05)$.

It can be concluded that the series of outdoor activities has a positive effect on the perceived selfefficacy of the participants.
\end{abstract}

Keywords: Self-Efficacy; Outdoor Education; Experiential Learning.

\section{Introduction}

Self-efficacy-sufficiency is one's belief in his/her ability to plan and to accomplish any task. This concept first emerged as part of Albert Bandura's theory of Cognitive Behavioral Change in 1977 (Albayrak Okçin ve Gerçeklioğlu 2013). One's belief of self-efficacy develops out of four sources.

\footnotetext{
${ }^{1}$ Researcher Assist., Abant Izzet Baysal University, Department of Sport Management, nuhosmanyildiz@gmail.com

${ }^{2}$ Assist. Prof., Abant Izzet Baysal University, Department of Sport Management, ozen g@ibu.edu.tr

${ }^{3}$ Researcher Assist., Kars Kafkas University, Department of Sport Management, tayfun-92@,hotmail.com
} 
These are:

1) Mastery experiences

2) Social modelling

3) Social persuasion, and

4) Physiological and emotional responses (Kurt ve Ekici, 2013).

Although these sources do not have a direct effect on personal self-efficacy, the personal interpretation of them may increase or decrease self-efficacy. It is known that people with a stronger sense of self-efficacy-sufficiency are more ambitious to take on and achieve challenging tasks, and put more effort in maintaining their thoughts and actions in order to succeed (Albayrak Okçin ve Gerçeklioğlu 2013). It is also known that one's life experiences during school years are important for a healthy adulthood. By observing the people and events around him since his childhood, an individual develops fairly coherent expectations of what results a given behaviour may yield as well as which events happen as a result of his behaviour (Yeşilyaprak, 1998). Therefore, an individual's life experiences since his childhood may increase or decrease his level of self-confidence. A strong sense of self efficacy has been found to be related with being healthier, more successful, and more adept in social integration (Özen et al., 2014). As one's belief in their ability to perform a task and success are correlated factors, the success of an individual depends on their belief of self-efficacy. The process of learning based on individuals' learning from their own lives and experiences, and developing themselves by reflecting on what is learned from the experience is called experiential learning (Kolb,1984). Outdoor Education is one of the many methods of experiential learning and plays an important role in helping one gain his/her self confidence. An analysis of the process and outcomes of outdoor education reveals that the natural setting and education provided in this particular setting is beneficial to the participants (Özen et al., 2014). Outdoor education also helps one gain a stronger sense of self-efficacy-sufficiency, which in turn enhances the ability to cope with stress. It has been suggested that, outdoor education enhances self-efficacy-sufficiency, therefore resulting in a greater chance for success in daily activities that involve problem solving and communication (Özen \& Vatansever, 2016). This study aims to determine whether there was any change in the level of self-efficacy of students who took part in a one-day outdoor education activity as a result of the education.

Outdoor education lasted one day and was designed in accordance with the literature. The outdoor education programme consisted of an opening meeting in which participants discussed the things to be done, and topics such as the comfort zone, learning by experience, and transfer of behaviours, two high-level activities, and an initiative activity based on communication and problem solving (Hahn, 1995; Garvey 1999).

\section{Methods}

This study employs the cross sectional method and makes use of survey data. The sample of survey is the same with target population of the study and is composed of 90 university students (50 men - 40 women), who play an active role in the Community of Mountain Climbing and Outdoor Sports and who volunteered for outdoor education. The participants were surveyed before and after the outdoor education activity. The Self-Efficacy Scale, developed by Sherer et al. (1982) and adapted to Turkish by Gözüm and Aksayan, was used for measurement.

\section{Data Collection Tool}

The Self-Efficacy Scale (SES) was developed by Sherer et al. (1982) and was adapted to Turkish and tested for reliability and validity by Gözüm and Aksayan (1999), whereby its Cronbach's Alpha internal consistency coefficient and test-retest reliability was found to be 0.81 and 0,92 , respectively. The Cronbach's alpha internal consistency coefficient for pre-test and posttest were found to be 0,74 and 0,86 , respectively, in our study.

The Self-efficacy Scale (SES) is a five-point Likert type self evaluation scale. In the 23-item scale, participants are asked to choose the one that defines him/her best from the following five 
statements for each item: 1- "Does not describe me at all."; 2- Describes me somewhat."; 3- "I am hesitant."; 4- "Describes me well."; and 5- "Describes me greatly." For each item, the score is the number chosen by the participant, except for items 2,4,5,6,7,10,11,12,14,16,17,18,20, and 22, for which reverse scoring is used. Therefore, one's score in the scale can range between 23 and 115 points, higher total scores indicating that the participant possesses a good level of self-efficacysufficiency.

In accordance with the recommendation of Gözüm and Aksayan (1999) that the scale be evaluated according to total score rather than sub-scales be analyzed independently as the distribution of the items in the sub-scales of the Turkish version of the Self-efficacy Scale differ in number, and as some items (11 and 19) do not accord well with their factors, the evaluation was made according to the total score in this study.

\section{Results}

A total of 90 people participated in the study, with $50(55.5 \%)$ males, and $40(44.5 \%)$ females (mean age 21.41 1 1.55).

Paired t-test was carried out to determine the effects of the activities carried out during the outdoor education on the self-efficacy scores of the participants, and the findings are shown on Table 1.

Table 1. Pre-test and Post-test Results of The Self-efficacy-sufficiency Scale

\begin{tabular}{ccccc}
\hline & $\mathbf{N}$ & & MEAN \pm SD & t \\
\hline \multirow{2}{*}{ Male } & \multirow{2}{*}{50} & pre-test & $92.58 \pm 3.11$ & $-3.96^{*}$ \\
& & post-test & $97.83 \pm 2.23$ & \\
\multirow{2}{*}{ Female } & \multirow{2}{*}{40} & pre-test & $95.31 \pm 3.78$ & $-3.50^{*}$ \\
& & post-test & $98.33 \pm 3.72$ & \multirow{2}{*}{ Total } \\
& \multirow{2}{*}{90} & pre-test & $93.79 \pm 3.78$ & \\
\hline$* \mathrm{p}<0,05$ & post-test & $98.05 \pm 5.16$ &
\end{tabular}

${ }^{*} \mathrm{p}<0,05$

The findings shown in Table 1 reveal that the pre-test and post-test scores for each group and the two groups combined significantly differ $(\mathrm{p}<0,05)$, with mean scores indicating an increase in the self-efficacy-sufficiency scores of the participants. These findings show that the outdoor education provided had a positive effect on the perceived self-efficacy-sufficiency of the participants.

Independent t-test was carried out to determine the extent to which the independent variable of gender contributed to the overall effects of the outdoor education on the self-efficacy scores of the participants, and the results are provided in Table 2.

Table 2. Pre-test - Post-test Scores According to Gender

\begin{tabular}{ccccc}
\hline & & N & MEAN \pm SD & t \\
\hline \multirow{2}{*}{ Pre-test } & Male & 50 & $92.58 \pm 3.11$ & -1.41 \\
& Female & 40 & $95.31 \pm 3.78$ & \\
Post-test & Male & 50 & $97.83 \pm 2.23$ & -1.01 \\
Difference in & Female & 40 & $98.33 \pm 3.72$ & \\
Differences & Male & 50 & $5.25 \pm 3.12$ & -1.99 \\
\hline
\end{tabular}

$* \mathrm{p}<0,05$ 
Yıldız, N. O., Özen, G., \& Bostanc1, T. G. (2016). The effects of one-day outdoor education on self- efficacy. Journal of Human Sciences, 13(3), 6098-6103. doi:10.14687/ihs.v13i3.4296

The findings provided in Table 2 show that there is no significant difference $(p<0,05)$ between the pre-test, post-test, and difference in differences scores as regards gender.

\section{Discussion and Conclusion}

Similar studies reported that rope track activities enhanced students' general belief of selfefficacy (Nyhus 1993, Nyhus et al., 1996; Constantine, 1993).

In another study that analyzed the effects of a two-day adventure training directed at improving managerial skills on the perceived self-efficacy of the 68 participants, it was found that the high-level activities carried out increased total self-efficacy scores significantly (Özen \& Yalçın, 2009). Graham \& Robinson (2007) found significant improvement in the perceived self-confidence of college students as a result of adventure training.

Bunting (2000) states that outdoor education provides the participant with an opportunity for a personal challenge, and the feeling of success and resistance that arises as a result of this challenge may influence the sense of self-efficacy, therefore helping the person to feel psychologically better.

In a study on the improvement of the competence of giving outdoor classes on science and environment, Carrier (2009) reported that once prospective teachers felt they were successful in performing activities related to science outdoors with students, their belief in their self-efficacy to facilitate outdoor activities of science with their students in the future increased. Based on the findings in the literature on outdoor and adventure learning programmes, McKenzie (2000) reported that there may be some benefits gained from these activities such as enhanced sense of self and interpersonal skills, yet there is a need for further empirical studies. Passarelli et al. (2010) stated that strengths-based interventions may be related to developmental outcomes, and despite being a relatively recent concept, strengths-based education is a promising field for future research.

These results are thought to have arisen due to the fact that participants of the outdoor education programme were forced out of their comfort zone through the activities, adapted themselves to the new situation, and experienced the "I can do" feeling.

In their study evaluating the self-efficacy-sufficiency levels of the students of a Health College, Yiğitbaş and Yetkin (2003) reported similar findings, and stated that since male and female students are enrolled in the same programme and are taught by the same teachers, they did not expect any difference in the self-efficacy-sufficiency scores in this respect. Keskin and Orgun (2006) reported that there was no significant difference in the self-efficacy-sufficiency scores of male and female students.

These findings are thought to be due to the fact that the participants in the aforementioned study had similar levels of education and worked under equal conditions, and that the activity did not differentiate between genders.

There are several studies on the effects of the variable of gender on the organization scheme and gains from the programme (Neill, 1997), and they report the positive acquisitions as a result of an outdoor activity in males and females to be similar (Hattie et al., 1997). Çelebi and Özen (2004) and Özen and Yalçin (2009) reported that the variable of gender has no effect on the outcomes of outdoor education given on rope tracks.

However, some studies claim gender differences in perception; when they achieve something, males attribute it to their abilities, whereas females focus on factors such as chance or particular effort (Witman, 1995).

The consequences of experience in nature are explored with regards to conceptions of nature place and outdoor learning for sustainability. Creative practices to tackle the crisis of perception are suggested as approaches that circumvent static conceptions of the world implied by points in relations and prevailing conceptions of nature as other. And it will be caused to improve personel improvment (Clarke\&Mcphie, 2014). Outdoor education, being a practice-based discipline that includes risk-taking adventures, obviously lends itself to building resilience. Hence, building resilience could contribute to qualification, socialisation and subjectification (Ho, 2014). 
Yıldız, N. O., Özen, G., \& Bostanc1, T. G. (2016). The effects of one-day outdoor education on self- efficacy. Journal of Human Sciences, 13(3), 6098-6103. doi:10.14687/jhs.v13i3.4296

We believe that the findings were directly affected by the fact that the participants in this study were all students of equal status and took an active role in the activities without any discrimination, and that each of the activities was designed in a way that would force the participants to leave their comfort zones and push their limits.

\section{Reference}

Albayrak Okcin, F. \& Gerçeklioğlu, G. (2013) Öğrencilerin öz etkililik-yetkililik algıları ve sosyal destek düzeylerinin incelenmesi, Gümüşhane University Journal of Health Sciences, 2(1): 42.

Bandura, A. (1977) Social Learning Theory. New York: General Learning Press.

Bunting, C. (2000). Outdoor adventure and health: supporting empirical data. in, coalition for education in the outdoors fifth biennial research symposium proceedings. Symposium Conducted At The Meeting Of The Education In The Outdoors Meeting, Bradford Woods, In

Clarke, D. \& Mcphie, J. (2014). Becoming animate in education: immanent materiality and outdoor learning for sustainability, Journal of Adventure Education and Outdoor Learning, 14(3): 198-216

Carrier, J. (2009), The effects of outdoor science lessons with elementary school students on preservice teachers' self-efficacy, Journal of Elementary Science Education, 21 (2): 35-48.

Constantine, M. (1993). The effects of ropes course experience on perceived self-efficacy: A study designed to examine the effects of an adventure program. The Pennsylvania Journal of Health, Physical Education, Recreation and Dance, 52(2): 10.

Çelebi, M.,Ozen, G. (2004). University students and adventure education programmes: A study of meanings and experience of adventure training activities. Outdoor and Adventure Education - Developments and Programmes. Symposium Conducted At The Meeting Of The International Conference On Leisure, Tourism \& Sport-Education, Integration, Innovation, Gologne, Germany.

Garvey, D. (1999). Do one day adventure programming activities, such as challenge courses, provide long lasting learning? Yes. In S. D. Wurdinger \& T. G. Potter (Eds.) Controversial Issues In Adventure Education A Critical Examination Dubuque, Iowa: Kendall Hunt-Publishing, S. 89-96.

Graham, L. B. \& Robinson, E. M. (2007). Project adventure and self-concept of academically talented adolescent boys. Physical Educator, 64(3), 114-122.

Gözüm, S. ve S. Aksayan. (1999). "Öz-Etkililik yeterlilik ölçeğinin türkçe formunun güvenirlik ve geçerliliğì”, Atatürk Üniversitesi Hemsirelik Yükesekokulu Dergisi, 2, 21-34.

Hahn, Kurt Address At the forty-eighth annual dinner of the old centralians, http://www.Kurthahn.Org/Writings/Oldcentral.Pdf).

Hattie, J.,Marsh, H. W., Neill, J. T., Richards, G. E. (1997). Adventure education and outward bound: out-of-class experiences that make a lasting difference. Review of Educational Research, 67: 43-87.

Ho, S. (2014) The purposes outdoor education does, could and should serve in Singapore, Journal of Adventure Education and Outdoor Learning, 14 (2): 153-171

Keskin, G. Ü., Orgun, F. (2006) Öğrencilerin öz etkililik-yeterlilik düzeyleri ile başa çıkma stratejilerinin incelenmesi, Anatolian journal of Psychiatry; 7: 92-99

Kolb, D. A. (1984). Experiential learning: experience as the source of learning and development. New Jersey: Prentice Hall, Inc.

Kurt,H. \& Ekici, G. (2013) The effect of the educational planning and evaluation lesson on preservice teachers' self-efficacy beliefs related to the teaching process'. Elementary Education Online, 12(4): 1157-1172. 

Human Sciences, 13(3), 6098-6103. doi:10.14687/jhs.v13i3.4296

MC Kenzie, M. D.(2000) How are adventure education program outcomes achieved?: A review of the literature. Australian Journal of Outdoor Education, 5 (1): 19-28.

Neill, J. T. (1997).Gender: How does it effect the outdoor education experience? B.Sc. (Hons) A Paper Presented To The 10th National Outdoor Education Conference, Sydney, Australia January $20-24$.

Nyhus, R. A (1993). The effect of adventure education over time on physical self-efficacy and taskspecific self-efficacy of college students. Dissertation Abstracts International, 54(10A): 3699

Nyhus, R. A., Npper-Owen, G., Phillips, D. A. (1996) The effect of an adventure education experience on the physical self-efficacy of college students (Abstract). Research Quarterly For Exercise and Sport. 67A, 86.

Özen, G., Yalçın, B. (2009) Macera eğitimi uygulamasının öz-etkililiğe etkisi, 5.Doğa Sporları ve Bilim Sempozyumu 13-14 Kasim, Ankara.

Özen, G., Özen, Ş. \& Sönmez Tiryaki. G. (2014). Kamp yaşantısı ve engel aktivitelerin katıllımcıların Öz-etkililik alg1larına etkisi. Spor ve Performans Arasstırmalar Dergisi 5/4 6.

Özen, G. \& Vatansever, Ş. (2016) Doğa eğitimi tabanlı serbest zaman etkinliklerinin üniversite öğrencilerinin denetim odağ üzerine etkisi. Uluslararası Türk Eğitim Bilimleri Dergisi, 4(6):103112.

Passarelli, A., Hall, E., Anderson, M. (2010). A strengths-based approach to outdoor and adventure education: Possibilities for personal growth, Journal of Experiential Education, 33 (2): 120-135.

Sherer, M. Et Al. (1982) The Self-Efficacy Scale Construction And Validation, Psychological Reports, 51,663-71

Witman, J. P. (1995) Characteristics of adventure programs valued by adolescents in treatment. Monograph on youth in the 1990s, 4: 127-135.

Yeşilyaprak, B. (1988). Lise öğrencilerinin içsel ya da dışsal denetimli oluşlarını etkileyen etmenler. Yaymlanmamış Doktora Teqi. Ankara: H.Ü. Sosyal Bilimler Enstitüsü.

Yiğitbaş, Ç., Yetkin, A. (2003) Sağlık yüksekokulu öğrencilerinin öz-etkililik-yeterlik düzeyinin değerlendirilmesi, C. Ü. Hemssirelik Yülesek Okulu Dergisi, 7 (1):6-13. 